\title{
Upregulation of MUC5AC production and deposition of LEWIS determinants by HELICOBACTER PYLORI facilitate gastric
} tissue colonization and the maintenance of infection

Weronika Gonciarz', Maria Walencka', Anthony P. Moran ${ }^{2 \wedge}$, Krzysztof Hinc $^{3}$, Michał Obuchowski ${ }^{3}$ and Magdalena Chmiela ${ }^{1 *}$

\begin{abstract}
Background: Helicobacter pylori bacteria colonize human gastric mucosa, cause chronic inflammation, peptic ulcers and gastric cancer. Colonization is mediated by H. pylori adhesins, which preferentially bind mucin 5 (MUC5AC) and Lewis (Le) determinants. The aim of this study was to evaluate the influence of $H$. pylori and their components on MUC5AC production and deposition of LeX/LeY in gastric epithelial cells in relation to bacterial adhesion using Caviae porcellus primary gastric epithelial cells and an in vivo model of experimental $H$. pylori infection in these animals.

Methods: MUCA5C and LeX/LeY were induced in vitro by live H. pylori reference strain CCUG $17874\left(2 \times 10^{7}\right.$ CFU/ $\mathrm{ml})$, H. pylori glycine acid extract (GE), $10 \mu \mathrm{g} / \mathrm{ml}$; cytotoxin associated gene A (CagA) protein, $1 \mu \mathrm{l} / \mathrm{ml}$; UreA urease subunit, $5 \mu \mathrm{g} / \mathrm{ml}$; lipopolysaccharide (LPS) $25 \mathrm{ng} / \mathrm{ml}$ and imaged by fluorescence microscopy after anti-MUC5AC or anti-LeX/LeY FITC antibody staining. Bacterial adhesion was imaged by using anti-H. pylori FITC antibodies. The animals were inoculated per os with H. pylori ( 3 times in 2 days intervals, $1 \times 10^{10} \mathrm{CFU} / \mathrm{ml}$ ). After 7 or 28 days an infection and inflammation were assessed by histological, serological and molecular methods. Gastric tissue sections of infected and control animals were screend for MUCA5C and LeX, and H. pylori adhesion as above.

Results: MUC5AC production and deposition of Lewis determinants, especially LeX were upregulated in the milieu of live H. pylori as well as GE, CagA, UreA or LPS in vitro and in vivo during infection, more effectively in the acute (7 days) than in the chronic (28 days) phase of infection. This was related to enhanced adhesion of H. pylori, which was abrogated by anti-MUC5AC and anti-LeX or anti-LeY antibody treatment.

Conclusions: Modulation of MUCA5C production and LeX/LeY deposition in the gastric mucosa by H. pylori can significantly increase gastric tissue colonization during $H$. pylori infection.
\end{abstract}

Keywords: MUC5AC, LewisX/Y, H. pylori, Guinea pigs

\footnotetext{
* Correspondence: chmiela@biol.uni.lodz.pl

Deceased

${ }^{1}$ Division of Gastroimmunology, Department of Immunology and Infectious Biology, Institute of Microbiology, Biotechnology and Immunology, Faculty of Biology and Environmental Protection, University of Łódź, Banacha 12/16, 90-237 Łódź, Poland

Full list of author information is available at the end of the article
}

(c) The Author(s). 2019 Open Access This article is distributed under the terms of the Creative Commons Attribution 4.0 International License (http://creativecommons.org/licenses/by/4.0/), which permits unrestricted use, distribution, and reproduction in any medium, provided you give appropriate credit to the original author(s) and the source, provide a link to the Creative Commons license, and indicate if changes were made. The Creative Commons Public Domain Dedication waiver (http://creativecommons.org/publicdomain/zero/1.0/) applies to the data made available in this article, unless otherwise stated. 


\section{Introduction}

The gastric mucosa is a physical barrier covered with a mucus layer, which protects stomach against harmful chemical, enzymatic, microbiological and mechanical factors [1, 2]. The integrity of gastric epithelial cells is maintained by tight junctions whereas cell proliferation promotes a renewal of this layer. Also the outer leyer of gastric mucosa loosely adheres to epithelium and is constantly removed and renewed, which protects a movement of pathogens to the stomach basement membrane [3, 4]. However, Helicobacter pylori Gram-negative microaerophilic rods, discovered by Warren and Marshall in 1983, are able to penetrate through gastric mucosa due to their spiral shape and flagella [5-8]. H. pylori can change the structure of mucus by thioredoxin, which reduces the disulfide bonds of mucins, thereby diminishing the capacity of mucin gel-formation [9]. Colonization of gastric mucosa is facilitated by urease, which generates ammonia neutralizing the acidic environment of the stomach $[10,11]$, and is followed by the reduction of mucus viscosity and elasticity $[12,13]$. In the case of strains positive for cytotoxin associated gene A (CagA) protein, colonization results in disruption the cell junctions and loss of cell polarity [14-16]. The cell damage induces infiltration of inflammatory cells including neutrophils, macrophages and lymphocytes and excessive gastrin versus decreased somatostatin production $[17,18]$. This results in an increased secretion of hydrochloric acid and movement of the gastric content with microorganisms into the duodenum, thus increasing the colonization area [19]. $H$. pylori infection may be asymptomatic or symptomatic with lesions, which arise after prolonged exposure to hydrochloric acid in the case of gastric or duodenal ulcers [20-22]. Initially active gastritis induced by $H$. pylori can transform into atrophic gastritis and then to neoplastic lesions and promote the development of mucosa-associated lymphoid tissue (MALT) lymphoma (0.1\%), or gastric adenocarcinoma [23-25]. Long-term colonization of gastric epithelial cells by $H$. pylori depends on various $H$. pylori surface adhesins including: the blood group antigen-binding adhesin A (BabA) and sialic acid binding adhesin (SabA), adherence-associated lipoprotein A (AlpA) and B (AlpB), Helicobacter outer membrane protein Z (HopZ), outer membrane protein A (OpiA) and proteins binding the host extracellular matrix components (ECM) [26-32]. Lipopolysaccharide (LPS) of $H$. pylori contains long-chain fatty acids and in the O-specific part there are sugar moieties similar to human Lewis (Le) blood-group antigens, which interact with corresponding sugar compounds of gastric mucin [33-37]. Among mucins, which are exposed on gastric epithelial cells the secretory mucin 5 (MUC5AC) is dominanting. This mucin can undergo modification to Le antigens, which play a role of receptors to $H$. pylori during infection [2, 37]. In humans Le antigens, especially Leb and LeX as well as sialylated LeX are the major putative receptors on gastric epithelial cells of the $H$. pylori infected host that bind $H$. pylori via BabA and SabA, respectively $[27,38-40]$. A heterogeneity among $H$. pylori strains in expression of the outer membrane protein BabA is postulated as pathogen fitness to diverse human population [41]. Bäckström et al. (2004) showed that $70 \%$ of Swedish and U.S. H. pylori clinical isolates exhibited Leb binding but the $b a b A$ gene was present in each of 10 Leb non-binding strains. Leb non-binding strains also possess silent $b a b A$ gene, which can be activated by recombination to $b a b B$ locus. At this locus, a $\mathrm{BabB} / \mathrm{A}$ chimeric adhesin is expressed and is subject to phase varaition (ON/OFF switching) [42]. Concerning SabA it's expression is also controlled via phase variation and the ArsRS signal transduction signal [43]. Various studies showed that MUC5AC with deposition of Le determinants is a key component of human gastric mucosa involved in $H$. pylori colonization. However, the knowledge about the influence of live bacteria or their soluble components on MUC5AC production as well as Le antigens deposition and management of $H$. pylori attachment to gastric epithelial cells and then colonization is insufficient. In this study, by using two Caviae porcellus (guinea pig) models: a model of primary gastric epithelial cells and a model of experimental $H$. pylori infection, we focused on the relation between MUC5AC and LeX/LeY production in response to gastric epithelial cell exposure in vivo or in vitro to $H$. pylori reference LeX/Y positive strain or soluble components of these bacteria, and the effectiveness of epithelial cell colonization. We considerd both the host and bacterial LeX/LeY components in the course of $H$. pylori adhesion to gastric epithelial cells on guinea pig model.

\section{Materials and methods}

\section{H. pylori strains and culture conditions}

Helicobacter pylori reference strain CCUG 17874 (Culture Collection, University of Gothenburg, Gothenburg, Sweden) positive for vacuolating cytotoxin A (VacA) and CagA proteins as well as for LeX and LeY determinants in LPS, which were confirmed previously by immunotyping with anti-LeX or anti-LeY antibodies [44], was used in this study. H. pylori bacteria were stored at $-80^{\circ} \mathrm{C}$ in Trypticase Soy Broth (TBS) containing $10 \%$ glycerol. Bacteria were cultured under 
microaerophilic conditions according to the previously described procedure [45].

\section{Stimuli}

Glycine acid extract (GE) from the reference $H$. pylori strain CCUG 17874 was a source of surface H. pylori antigens, which were extracted using $0.2 \mathrm{~mol} / \mathrm{l}$ glycine buffer, $\mathrm{pH} 2.2$, as previously described [46, 47]. Protein composition of GE was evaluated by SDS-PAGE electrophoresis and Western blot - Immuno blot (Milenia ${ }^{\circ}$ Blot H. pylori, DPC Biermann, GmbH, Bad Nauheim, Germany), with the reference serum samples from patients infected with $H$. pylori [48]. Major proteins in GE recognized by sera from $H$. pylori infected patients were: $120 \mathrm{kDa}(\mathrm{CagA}), 87 \mathrm{kDa}$ (VacA), $66 \mathrm{kDa}$ (UreB), $60 \mathrm{kDa}$ (Hsp), $29 \mathrm{kDa}$ (UreA), between 66 and $22 \mathrm{kDa}$. The protein concentration in GE was $600 \mu \mathrm{g} / \mathrm{ml}$ (NanoDrop 2000c Spectrophotometer, ThermoScientific, Wlatman, WY, United States). GE contained $<0.001 \mathrm{EU} / \mathrm{ml}$ of LPS, as shown by the chromogenic Limulus amebocyte lysate test (Lonza, Braine-Alleud, Belgium). GE was applied at $10 \mu \mathrm{g} / \mathrm{ml}$. Recombinant CagA protein - rCagA (a kind gift from Antonello Covacci, IRIS, Siena, Italy), was used at $1 \mu \mathrm{g} / \mathrm{ml}$. A recombinant fragment of CagA antigen of $H$. pylori: nt 2777 to nt 3465 of cagA gene was used. It was expressed (QIAexpress System, Qiagen, Hilden, Germany) in E. coli as a fusion protein (about $26 \mathrm{kDa}$ size) with a 6 His-tail in front of a 230 aa polypeptide of CagA. The protein was purified by the $\mathrm{Ni}^{2}{ }^{+}$ ${ }^{-}$NTA agarose column, and checked for serological activity by the enzyme immunoassay $[49,50]$. Due to patent claims of $H$. pylori urease the UreA subunit from $H$. acinonychis isolated from the acidic environment of cheetah stomach was used as a homoloque of $H$. pylori protein (97\% homology). The urease gene was amplified by PCR, as previously described [51], using chromosomal DNA as a template and oligonucleotides hisure-A-up and hisure-A-dn as primers. DNA encoding six histidines (His6-tag) was carried by oligonucleotide hisure-A-dn. The obtained PCR product of $737 \mathrm{bp}$ was digested with enzymes KpnI and NheI and cloned into the commercial vector pBAD (Stratagene, California, United States). The resulting plasmid, pMD1, was verified by restriction analysis and nucleotide sequencing. pMD1 was used to transform the E. coli strain DH5a and the recombinant strain was used to overproduce UreA by the addition of arabinose $0.05 \%$. A $27 \mathrm{kDa}$ protein was visualized on a coomassie blue stained gel and purified on Ni-NTA superflow agarose (Qiagen) followed by gel filtration on Superose 6resin. UreA was used at $5 \mu \mathrm{g} / \mathrm{ml}$. LPS from the reference strain of $H$. pylori CCUG 17874 was prepared by hot phenol-water extraction. Whole cell lysates were pretreated with proteinase K (Sigma, St Louis, MI, United States). Crude extraction of LPS from bacteria was performed with $45 \%$ aqueous phenol at $68^{\circ} \mathrm{C}$ for $30 \mathrm{~min}$. The LPS preparation was purified by the treatment with RNase A, DNase II and proteinase K (Sigma), and by ultracentrifugation at $100000 \times g$ at $4{ }^{\circ} \mathrm{C}$, for $18 \mathrm{~h}$ [52-54]. H. pylori LPS and control LPS of E. coli (serotype O55: B5; Sigma) were used at $25 \mathrm{ng} / \mathrm{ml}$. The antigen concentrations were adjusted experimentally or adopted from previous studies [55-57].

\section{H. pylori infection in Guinea pigs}

Adult, three-month-old, 400-600 g of weight male Himalayan Cavia porcellus (guinea pigs) were used in the experiments. Animals were bred in the Animal House at the Faculty of Biology and Environmental Protection, University of Lodz (Poland), kept in cages with free access to drinking water and fed with standard chow. The experiments were approved by the Local Ethics Committee LKE9 (Decision 58/ŁB45/2016). The animal study groups consisted of guinea pigs $(n=15)$, which were inoculated per os three times (at two-day intervals) with $1 \mathrm{ml}$ of sterile complete Brucella broth using a feeding needle (control group; $n=5$ ), or with 1 $\mathrm{ml}$ of freshly prepared suspension of $H$. pylori $\left(1 \times 10^{10}\right.$ colony forming units - CFU)/ml; $n=10$ ). Before the administration of complete Brucella broth or H. pylori suspension, the animals obtained orally $1 \mathrm{ml}$ of $0.2 \mathrm{M}$ $\mathrm{NaHCO}_{3}$ to quickly neutralize the acidic $\mathrm{pH}$ of the stomach. 7 and 28 days after the last dose of $H$. pylori the guinea pigs were euthanized, and biological samples were collected for further study. H. pylori status was confirmed according to previously described methods $[45,57]$. Anti-H. pylori IgG/IgM antibody content in the serum samples, and the level of $H$. pylori antigens in the stool were detected by enzyme-linked immunosorbent assay (ELISA). Histopathological methods were used to detect Helicobacter-like organisms (HLO) and inflammation whereas polymerase chain reaction (PCR) was applied to detected cagA and ure $C$ gene sequences in the guinea pigs gastric tissue.

\section{Cell cultures}

Primary gastric epithelial cells were obtained according to the previously described procedures [58-60], with some modifications. The guinea pig was euthanized by overdosing sodium barbiturate (Morbital, Biowet, Poland), the stomach was isolated, rinsed with Hank's Balanced Salt Solution (HBSS), pH 7.4 (Sigma) supplemented with penicillin $(100 \mathrm{U} / \mathrm{ml})$, streptomycin $(100 \mu \mathrm{g} / \mathrm{ml})$ and amphotericin B $(0.025 \mathrm{mg} / \mathrm{ml})$ (Polfa Tarchomin S.A., Warszawa, Poland), homogenized and then tripsinized ( $15 \mathrm{~min}$., room temp). Next, $2 \%$ bovine serum albumin (BSA) solution (Sigma) in HBSS was added to homogenates, which were then 
centrifuged at $3000 \times g$ for $15 \mathrm{~min}$. The supernatant was removed and the pellet was suspended in 5\% BSA in Dulbecco's Modified Eagle's medium (DMEM) (Sigma) supplemented with penicillin $(100 \mathrm{U} / \mathrm{ml})$, streptomycin $(100 \mu \mathrm{g} / \mathrm{ml})$ and amphotericin B $(0.025$ $\mathrm{mg} / \mathrm{ml}$ ) (Polfa). Cell suspensions $2 \times 10^{6}$ cells $/ \mathrm{ml}$ were added to the wells of 6-well plates (Becton Dickinson, USA), and incubated for $24 \mathrm{~h}\left(5 \% \mathrm{CO}_{2}, 37^{\circ} \mathrm{C}\right)$ to adhere. Unbound cells were washed out with phosphate-buffered saline (PBS), pH 7.4 and the remaining cells were cultured with DMEM and Ham's F-12 1: 1 (Sigma) supplemented with $10 \%$ fetal calf serum (FCS), 1\% N-2-hydroxyethylpiperazine-N-2-ethane sulfonicacid (HEPES) (Sigma), penicillin (100 U/ $\mathrm{ml})$, streptomycin $(100 \mu \mathrm{g} / \mathrm{ml})$, amphotericin B $(0.025 \mu \mathrm{g} / \mathrm{ml})$, L-glutamine $(2 \mathrm{mM} / \mathrm{ml})$ (Polfa), epidermal growth factor (Sigma) $0.01 \mu \mathrm{g} / \mathrm{ml}$ and $0.005 \%$ dexamethasone solution in complete RPMI-1640 culture medium (cRPMI) (Sigma). Every $48 \mathrm{~h}$, the medium was changed and after 8 days of cultivation, confluent monolayers were treated with $0.25 \%$ trypsin (BIOMED-LUBLIN, Lublin, Poland) and transferred to breeding bottles. After 14 days cells were used for testing.

\section{Evaluation of MUC5AC and LeX or LeY dependent $H$. pylori adhesion to Guinea pig primary gastric epithelial cells}

Primary gastric epithelial cells $\left(1 \times 10^{6}\right.$ cell $\left./ \mathrm{ml}, 1 \mathrm{ml}\right)$ were cultured in DMEM: $\mathrm{F} 12$ medium $\left(37^{\circ} \mathrm{C}, 5 \% \mathrm{CO}_{2}\right)$ in wells of a 6-well culture plates containing glass coverslips (ThermoScientific, USA). Unstimulated cells (control) or cells stimulated for $24 \mathrm{~h}$ with selected $H$. pylori antigens: GE $10 \mu \mathrm{g} / \mathrm{ml}$, CagA $1 \mu \mathrm{g} / \mathrm{ml}$, UreA $5 \mu \mathrm{g} / \mathrm{ml}$ and H. pylori/E. coli LPS (control), $25 \mathrm{ng} / \mathrm{ml}$ or for $2 \mathrm{~h}$ with live H. pylori $\left(2 \times 10^{7} \mathrm{CFU} / \mathrm{ml}\right)$ were fixed with $4 \%$ formaldehyde solution, $20 \mathrm{~min}$, room temp., and then washed 3 times in PBS. For increasing cell permeability cells were treated with $0.2 \%$ Triton-X-100 for $10 \mathrm{~min}$ and then washed 3 times as before. After blocking an unbound glass with $3 \%$ BSA in PBS, $1 \mathrm{~h}$, cells were used for further procedures. The production of mucin and Le $\mathrm{X}$ or Le $\mathrm{Y}$ determinants was evaluated by incubating cells with primary mouse anti-MUC5AC antibodies (MyBiosource, USA), diluted 1: 200 in PBS/BSA or anti-Le X/Le Y antibodies (Dako, Glostrup, Denmark), $2 \mu \mathrm{g} / \mathrm{ml}$, for $2 \mathrm{~h}$ at room temp. After washing the excess of antibodies away, cells were incubated for $1 \mathrm{~h}$ in the dark with sheep anti-mouse immunoglobulins antibodies $(100 \mu \mathrm{l})$ conjugated with fluorescein isothiocyanate (FITC) (Sigma), diluted 1: 64 in PBS/BSA. In parallel, cells exposed to $H$. pylori antigens, treated or not treated with anti-MUC5A antibodies or anti- LeX/LeY antibodies (Dako), and then incubated with live H. pylori (1 $\mathrm{ml}, 2 \times 10^{7} \mathrm{CFU} / \mathrm{ml}, 2 \mathrm{~h}, 37^{\circ} \mathrm{C}, 5 \% \mathrm{CO}_{2}$ ) were used. The unbound bacteria were washed out, and cells were incubated for $1 \mathrm{~h}$ with rabbit anti-H. pylori antibodies - FITC (100 $\mu \mathrm{l}, 1: 200$ in BSA/PBS) (MyBiosource). Cells were then stained with Texas Red-X phalloidin (Thermo Scientific) solution $(2.5 \mu \mathrm{g} / \mathrm{ml}), 15 \mathrm{~min}$ at room temp, and with 4',6-diamidino-2-phenylindole (DAPI; Sigma) solution $(2.5 \mu \mathrm{g} / \mathrm{ml})$ at the same conditions. Slides were mounted in a DPX balsam (Surgipath, Great Britan) and then imaged in a confocal microscope (Leica TCS SPE) at a wavelength for FITC $495 \mathrm{~nm}$ (excitation), $519 \mathrm{~nm}$ (emission); for phalloidyne $591 \mathrm{~nm}$ (excitation), $608 \mathrm{~nm}$ (emission) and for DAPI $358 \mathrm{~nm}$ (excitation), $461 \mathrm{~nm}$ (emission), at $640 \times$ magnification. In all experiments, controls of antibodies were set to exclude non-specific reactions. Three independent experiments and replications were performed.The production of MUC5A or LeX/LeY was assessed quantitatively on the basis of green fluorescence intensity measured using a multifunctional Victor 2 reader (Wallac, Oy, Turku, Finland), and by fluorescence imaging $[56,61]$.

\section{Detection of MUC5AC, LeX and H. pylori bound to the Guinea pig gastric tissue}

Guinea pig gastric tissue specimens ( 7 and 28 days after inoculation with $H$. pylori or control) fixed in formalin, embedded in paraffin were cuted to tissue sections $(4 \mu \mathrm{m})$, which were placed on the adhesive slide and then deparaffinized. For antigen exposure they were heated $\left(95-100^{\circ} \mathrm{C}\right)$ in sodium citrate buffer $\mathrm{pH} 6.0,20$ min, cooled to room temp. and washed 3 times in PBS. The slides were blocked for $1 \mathrm{~h}$ (BSA/PBS) and washed as above. MUC5AC was stained with mouse anti-MUC5AC antibodies 1:100 (MyBiosource, USA), whereas LeX with anti-LeX antibodies (DAKO), $2 \mu \mathrm{g} / \mathrm{ml}$, overnight at $4{ }^{\circ} \mathrm{C}$. After washing 5 times in Tris-Buffered Saline with Tween 20 (TBST), pH 7.4, sheep anti-mouse IgG antibodies conjugated with FITC (Sigma),1:64, were added on slides, which were incubated for $20 \mathrm{~min}$ at room temp. Cell nuclei were stained with DAPI solution $(2.5 \mu \mathrm{g} / \mathrm{ml})$ or phalloidine, $15 \mathrm{~min}$, at room temp, as above. Intensity of fluorescence was measured by using the software Image $1.48 \mathrm{v}$ (National Institute of Health, United States) under fluorescence microscope (Zeiss, Axio Scope, A1, Germany) at an appropriate wavelength: for FITC $495 \mathrm{~nm}$ (excitation)/519 nm (emission); for phalloidyne $591 \mathrm{~nm}$ (excitation)/608 nm (emission), and for DAPI $358 \mathrm{~nm}$ (excitation)/461 nm (emission), at $100 \times$ magnification $[56,61]$. The ability of $H$. pylori to bind MUC5AC or LeX was assessed on tissue sections preincubated with blocking anti-MUC5AC or anti-LeX antibodies, or control unblocked sections, which were then incubated with $H$. pylori $\left(2 \times 10^{7} \mathrm{CFU} / \mathrm{ml}\right)$ for $2 \mathrm{~h}$. After washing the specimens were stained with rabbit 
anti-H. pylori antibodies FITC and with DAPI, and fluorescence intensity was evaluated by imaging in fluorescence microscope as above.

\section{Statistical analysis}

Data were expressed as the mean \pm standard deviation (SD). The differences between groups were tested using the non-parametric Mann-Whitney $U$ test or the Kruskal-Wallis test. For statistical analysis the Statistica 12 PL software was used. Results were considered statistically significant when $p<0.05$.

\section{Results}

MUC5AC and LeX/LeY production by Guinea pigs gastric epithelial cells in the milieu of live $H$. pylori or soluble compounds of these bacteria in relation to $\mathrm{H}$. pylori adhesion - In vitro and in vivo models

We were focused on answering the question whether live $H$. pylori rods or their soluble antigens modulate MUC5AC production by the gastric epithelial cells and LeX/LeY deposition, and how it influences the process of colonization of gastric mucosa by $H$. pylori using an in vitro model of primary gastric epithelial cells derived from the guinea pig gastric tissue. We also used an in vivo model of experimental infection with $H$. pylori in these animals. Production of MUC5AC was significantly increased after $24 \mathrm{~h}$ stimulation of guinea pig primary gastric epithelial cells with $H$. pylori surface components GE $(10 \mu \mathrm{g} / \mathrm{ml})$, CagA $(1 \mu \mathrm{g} / \mathrm{ml})$, UreA $(5 \mu \mathrm{g} / \mathrm{ml})$, H. pylori LPS $(25 \mathrm{ng} /$ $\mathrm{ml}$ ) as well as after $2 \mathrm{~h}$ stimulation with live $H$. pylori $\left(2 \times 10^{7} \mathrm{CFU} / \mathrm{ml}\right)$ (Fig. 1a), $p<0.05$ in Kruskal-Wallis test. The highest fluorescence after staining the cells with anti-MUC5AC and secondary FITC labeled antibodies was demonstrated for cells treated with $\mathrm{H}$. pylori LPS. Increased production of MUC5AC was corelated with the elevated levels of LeX in all variants of cell cultures, $\mathrm{p}<0.05$ in Kruskal-Wallis test, especially in the cell cultures treated with live $H . p y l$ ori or H. pylori LPS. Deposition of LeY in primary gastric epithelial cells was elevated in cell cultures exposed to whole $H$. pylori, UreA and $H$. pylori LPS (Fig. 1a i). Similarly, MUC5AC production increased in the gastric tissue of guinea pigs inoculated experimentaly with $H$. pylori (Fig. 1b). Only in the gastric mucosa of infected but not of uninfected animals the gastric tissue was positive for $\mathrm{HLO}$, ureC/cagA and infiltrated by immunocompetent cells. After 28 days from inoculation of animals with $H$. pylori the number of eosinophils and lymphocytes increased, which indicated the development of chronic inflammatory response. H. pylori antigens were detected in stool samples and anti- $H$. pylori antibodies in the sera of infected but not of uninfected animals ( 7 and 28 days post infection). Significantly higher levels of MUC5AC were demonstrated in animals 7 (acute phase of infection) than 28 days after the last $H$. pylori inoculation (chronic phase of infection) (Fig. 1b i, 1b ii). The production of MUC5AC was linked with the elevated deposition of LeX in gastric tissue, which was stronger after 7 than 28 days post infection (Fig. $1 \mathrm{c}$ i, ii), $p<$ 0.05 in Kruskal-Wallis test.

The mucin production and LeX or LeY deposition were then compared to the effectiveness of $H$. pylori adhesion to guinea pig gastric epithelial cells in vitro and in vivo. To determine whether MUC5AC or LeX/LeY mediated the adhesion of $H$. pylori to the guinea pig gastric epithelium we used guinea pig primary gastric epithelial cells preincubated or not with $H$. pylori components and then untreated or treated with anti-MUC5AC, anti-LeX or anti-LeY blocking antibodies (Fig. 2a i, ii, iii) before the exposure to live H. pylori. The results presented in Fig. 2a i, ii, iii show that increased adhesion of $H$. pylori to guinea pig primary gastric epithelial cells was related to the elevated production of MUC5AC in these cells, in response to live H. pylori and soluble components of these bacteria, and was completely abrogated by anti-MUC5AC antibodies (Fig. 2a i, ii, iii). Similarly, Fig. $2 \mathrm{~b}$ i, ii show the results for guinea pig gastric tissue specimens untreated or treated with anti-MUC5AC antibodies and then exposed to live $H$. pylori in vitro. The attachment of $H$. pylori to guinea pig gastric tissue specimens was diminished by the pretreatment of tissue sections with anti-MUC5AC antibodies (Fig. 2b i, ii, iii). Furthermore, it was showed that LeX and LeY determinants mediated the binding of $H$. pylori to primary gastric epithelial cells because $H$. pylori binding to these cells was significantly diminished by pretreatment the cells with anti-LeX or anti-LeY antibodies (Fig. 2a i). Similarly, the attachment of $H$. pylori to gastric tissue specimens was abrogated after treatment of specimens with anti-LeX antibodies (Fig. 2c i, ii, iii).

Live $H$. pylori stimulated MUC5AC significantly higher that of E.coli LPS. Similarly, the deposition of LeX determinants was higher in response to live $H$. pylori than to LPS E.coli (Fig. 1a i). The adhesion assay showed that MUC5AC, which was exposed on the cells treated with live H. pylori or LPS E.coli was used by $H$. pylori for binding. This was confirmed by blocking of $H$. pylori attachment with anti-MUC5AC (Fig. 2 b i). However, it is possible that E. coli LPS could stimulated other than LeX or LeY determinats, not considered in this study, that could mediate adhesion of $H$. pylori.

Because LPS of $H$. pylori strain used in this study contains LeX and LeY determinants we asked whether these determinants mediate bacterial binding to primary gastric epithelial cells. For binding experiments 


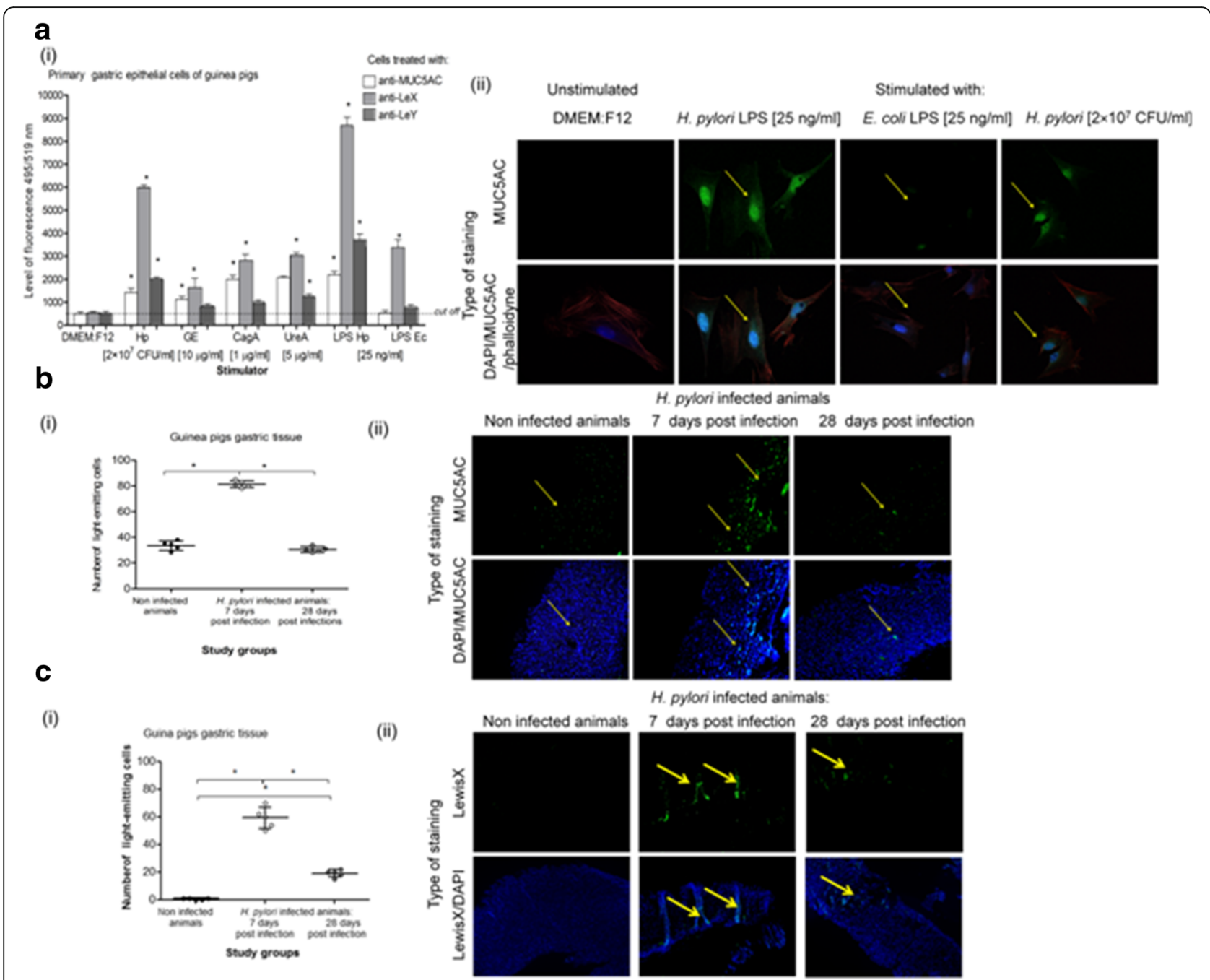

Fig. 1 MUC5AC and Lewis X/Y production by guinea pig gastric epithelial cells. MUC5AC and Lewix X/Y was evaluated on the basis of the intensity of fluorescence of guinea pig primary gastric epithelial cells or gastric tissue specimens stained with mouse anti-MUC5AC or anti-LeX/ anti-LeY antibodies (Ab) and secondary antibodies conjugated with fluoresceine isothiocyanate (FITC) and counterstained with DAPI or phalloidine. a- guinea pig primary gastric epithelial cells non treated (in culture medium alone) or treated with selected $H$. pylori components: for $24 \mathrm{~h}$ with glycine acid extract - GE $(10 \mu \mathrm{g} / \mathrm{ml})$, urease subunite A - UreA $(5 \mu \mathrm{g} / \mathrm{ml})$, cytotoxin associated gene A (CagA) protein $(1 \mu \mathrm{g} / \mathrm{ml})$, H. pylori lipopolysaccharide (LPS Hp) or E.coli LPS -LPS EC $(25 \mathrm{ng} / \mathrm{ml})$ or for $2 \mathrm{~h}$ with live H. pylori - Hp $\left(2 \times 10^{7}\right.$ colony forming units - CFU/ml), (i) intensity of fluorescence measured in a fluorescence reader at $495 \mathrm{~nm}$ (excitation) and $519 \mathrm{~nm}$ (emission), mean values \pm SD. * Statistical significance for $p$ $<0.05$ assessed by non parametric U Mann-Whitney test, (ii) representative images from a confocal microscope (Leica TCS SPE) at wavelengths: FITC - $495 \mathrm{~nm}$ excitation and $519 \mathrm{~nm}$ emission, DAPI - $345 \mathrm{~nm}$ excitation and $455 \mathrm{~nm}$ emission, phalloidine - $591 \mathrm{~nm}$ excitation and $608 \mathrm{~nm}$ emission (630 x magnification). b MUC5AC and c Lewis X imaging in the gastric tissue of guinea pigs experimentally infected with $\mathrm{H}$. pylori $(7$ and 28 days after inoculation, $n=10$ ) or control animals $(n=5)$, (bi, ci) intensity of fluorescence measured using the software ImageJ version $1.48 \mathrm{~V}$ (National Institute of Health, United States) at $495 \mathrm{na}$ (excitation) and $519 \mathrm{~nm}$ (emission), mean values \pm SD. Statistical significance for $p<0.05$ assessed by the non parametric Kruskal-Wallis test. * Statistically siginificant values for infected animals (7 and 28 days after inoculation) vs control animals and for infected animals 7 days post infection vs 28 days after the last inoculation with H. pylori, b ii representattive images of MUC5AC production and $\mathrm{c}$ ii representative images of LeX production in guinea pigs gastric tissue from fluorescence microscope (Axio Scope A1, Zeiss, Germany) at wavelengths: FITC $495 \mathrm{~nm}$ excitation and $519 \mathrm{~nm}$ emission, DAPI $345 \mathrm{~nm}$ excitation and $455 \mathrm{~nm}$ emission, (100× magnification)

H. pylori untreated or treated with anti-LeX or anti-LeY antibodies were used. The binding effectiveness of $H$. pylori pre-treated with anti-LeX alone or in combination with anti-LeY antibodies was diminished significantly, $38 \pm 0.5 \%$ and $44 \pm 0.8 \%$, respectively, $p<0.05$ in U Mann-Whitney test (Fig. 3)

\section{Discussion}

Since the description of $H$. pylori for the first time by $\mathrm{R}$. Warren and B. Marshall in 1983, many aspects related to the host gastric epithelial cells colonization and pathogenesis of $H$. pylori have been intensively studied in order to understand the mechanisms of infection 


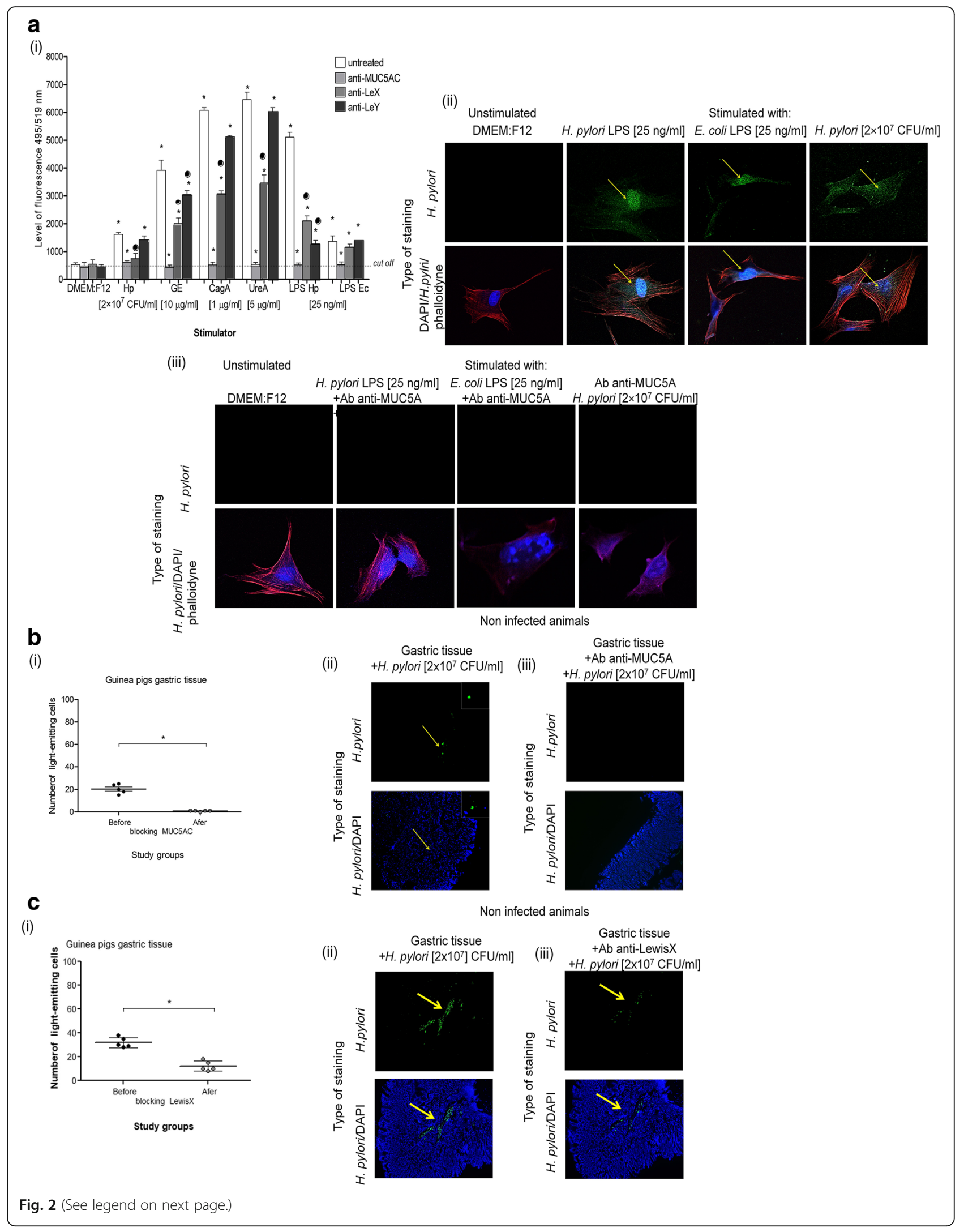


(See figure on previous page.)

Fig. 2 Adhesion of H. pylori to guinea pig gastric epithelial cells mediated by MUC5AC mucin and Lewis (Le)X/LeY determinants. Binding of $H$. pylori to guinea pig primary gastric epithelial cells and gastric tissue specimens was evaluated by imaging $\mathrm{H}$. pylori stained with anti-H. pylori antibodies (Ab) conjugated with fluorescein isothiocyanate (FITC) in a fluorescence reader or confocal microscope, counterstained with DAPI or phalloidine. a - guinea pig primary gastric epithelial cells non treated (in culture medium alone) or treated with selected $H$. pylori components: for $24 \mathrm{~h}$ with glycine acid extract - GE $(10 \mu \mathrm{g} / \mathrm{ml})$, urease subunite $\mathrm{A}$ - UreA $(5 \mu \mathrm{g} / \mathrm{ml})$, cytotoxin associated gene A $($ CagA) protein $(1 \mu \mathrm{g} / \mathrm{ml}), \mathrm{H}$. pylori lipopolysaccharide (LPS Hp) or E.coli LPS -LPS Ec $(25 \mathrm{ng} / \mathrm{ml})$ or for $2 \mathrm{~h}$ with live $\mathrm{H}$. pylori - Hp $\left(2 \times 10^{7}\right.$ colony forming units - CFU/ml) were prepared. Further, cells non-treated (control of adhesion) or blocked with anti-MUC5AC or with anti-LeX/LeY antibodies were used in adhesion assay. a i - the intensity of fluorescence measured in a fluorescence reader at $495 \mathrm{~nm}$ (excitation) and $519 \mathrm{~nm}$ (emission), mean values \pm SD. * Statistical significance for cells treated with an individual component vs untreated cells or \# treated with individual antibody vs untreated cells (control cells), $\mathrm{p}<0.05$ in non parametric $U$ Mann-Whitney test. Representative images of primary gastric epithelial cells untreated (a ii) or treated (a iii) with anti-MUC5AC antibodies before H. pylori binding experiments, stained with anti-H. pylori FITC antibodies in confocal microscope (Leica TCS SPE), at $495 \mathrm{~nm}$ excitation and 519 emission for FITC, 345 excitation/455 emission for DAPI and $591 \mathrm{~nm}$ excitation/608 nm emission for phalloidine (640 magnification). Gastric tissue specimens from non infected guinea pigs untreated or treated with anti-MUC5AC (b) or anti-LeX (c) blocking antibodies before $2 \mathrm{~h}$ exposure to live $\mathrm{H}$. pylori $\left(2 \times 10^{7}\right.$ colony forming units (CFU)/ml). bi and $\mathrm{Ci}$ - intensity of fluorescence measured using the software ImageJ version 1.48v (National Institute of Health, United States) at 495 excitation/519 emission, mean values \pm SD. *Statistically significant values for gastric tissue blocked with anti-MUC5AC or anti-LeX antibodies vs unblocked specimens. Representative images of $\mathrm{H}$. pylori adhesion to the guinea pig gastric tissue non treated with anti-MUC5AC (bii) or anti-LeX (cii) antibodies vs gastric tissue treated with such antibodies (b iii, iii) from fluorescence microscope (Axio Scope A1, Zeiss, Germany), at $495 \mathrm{~nm}$ excitation/519 nm emission for FITC, $345 \mathrm{~nm}$ excitation/455 nm emission for DAPI and $591 \mathrm{~nm}$ excitation/608 nm emission for phalloidine (100 × magnification)

especially in view of its chronic nature and pathological consequences [7, 62-65]. Studies on the pathogenesis of H. pylori infections require appropriate models, both cellular in vitro models and in vivo animal models [6668]. The most suitable model is Caviae porcellus (guinea

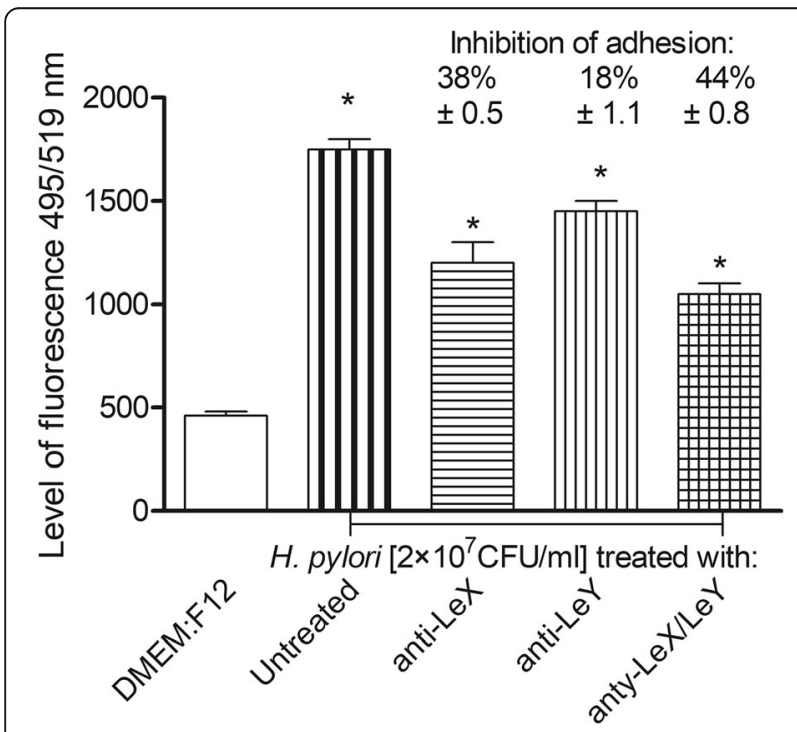

Fig. 3 Involvement of $H$. pylori Lewis (Le) $X$ or LeY determinents in adhesion to guinea pig primary gastric epithelial cells. Binding of $H$. pylori to gastric epithelial cells was evaluated by imaging $H$. pylori stained with anti-H. pylori antibodies (Ab) conjugated with fluoresceine isothiocyanate (FITC). Gastric epithelial cells were cocultured for $2 \mathrm{~h}$ with live $\mathrm{H}$. pylori $\left(2 \times 10^{7}\right.$ colony forming units CFU/ml) non treated or treated for 30 min with anti-LeX, anti-LeY or both types of antibodies. The intensity of fluorescence was measured in a fluorescence reader at $495 \mathrm{~nm}$ excitation/519 nm emission, mean values \pm SD. * Statistical significance for cells exposed to $H$. pylori untreated with anti-LeX or anti-LeX and anti-LeY antibodies, vs cells exposed to $H$. pylori, treated such antibodies, $p<$ 0.05 in the non parametric $U$ Mann-Whitney test pig), due to the anatomy and physiology of its stomach, which is similar to the human stomach, lack of natural H. pylori infection, ability to produce a homologue of human proinflammatory interleukin (IL) 8, and to develop both humoral and cellular specific immune responses to these bacteria as well as the need of external source of vitamin $C[67,68]$. The phenomenon of $H$. pylori adhesion to the surface of gastric epithelial cells is crucial for colonization and maintenance of infection, which is accompanied by a chronic inflammatory reaction. The aim of this study was to evaluate the role of $H$. pylori and their solube components in MUC5AC production by gastric epithelial cells and the exposure of LeX/LeY determinants and their role in the attachment of these bacteria to the gastric tissue. Whether soluble components of these bacteria modulate the production of mucin components, including Lewis antigens and how they favor colonization of the gastric tissue and the maintenance of infection by these bacteria is not completely understood. In this study we used primary gastric epithelial cells derived from the guinea pig stomach as well as an in vivo model of experimental infection in these animals, lasting for 7 or 28 days, to follow the production of MUC5AC and deposition of LeX/LeY in the milieu of selected $H$. pylori components in cell cultures or in response to gastric tissue infection. The question was whether there is a relationship between the production of MUC5AC and LeX/LeY deposition, and the binding effectiveness of $H$. pylori to gastric epithelial cells. Mucin MUC5AC was suggested to be the main source of host receptors for $H$. pylori during colonization of gastric tissue in humans [69]. We showed that MUC5AC was produced by guinea pig primary gastric epithelial cells after $24 \mathrm{~h}$ incubation with $H$. pylori antigens used in this study such as: GE, CagA, UreA, LPS and after $2 \mathrm{~h}$ 
exposure to live bacteria. MUC5AC was most intensively produced in response to stimulation with $H$. pylori LPS but not E. coli LPS. Probably this is because H. pylori LPS contains fucosylated oligosaccharide antigens identical to human antigens Lea, Leb, sLeX, sLeY, $\mathrm{H}$ type 1 and $\mathrm{A}, \mathrm{B}$ antigens of the $\mathrm{ABO}$ blood group system, whose expression changes during the inflammatory response [35, 70-73]. Van den Brink et al. (2000) and later Park et al. (2015) confirmed the expression of MUC5AC in the human stomach and demonstrated the importance of MUC5AC in gastric mucosa colonization by $H$. pylori [74]. In humans binding of $H$. pylori with Leb and sialylated determinants of MUC5AC such as sLeX in the gastric mucosa is mediated by surface $H$. pylori adhesins such as BabA and SabA, respectively [27, 28, 31, 36, 75]. H. pylori with a deletion of the $b a b A$ gene was found clearly less effective in binding mucin than wild strain [42]. In our study the increased production of MUC5AC in in vitro model of guinea pig primary gastric epithelial cells was related to elevated deposition of Lewis determinants: LeX and LeY in response to live H. pylori, UreA and $H$. pylori LPS. Other $H$. pylori components such as GE or CagA and the reference LPS E. coli increased the deposition of LeX rather than LeY. Considering the islad-like character of $H$. pylori infection it is possible that different $H$. pylori soluble components may influence locally the production of gastric mucus containing MUC5AC as well as LeX/Y, which can be involved in binding these bacteria in dose dependent manner. Interaction of $H$. pylori with mucins and colonization effectiveness were also confirmed by the study on three cell lines grown on "transwel" type filters: HT29 (non-mucin secreting line), HT29-MTX (native, mucin secreting), HT29- MTX-E13 (containing an adherent mucus layer). H. pylori colonized the HT29-MTX-E13 cells most intensively, while the HT29 line was not colonized by these bacteria [76]. Park et al. (2015) showed H. pylori binding to mucins (including MUC5AC) isolated from gastric juice and gastric biopsies from patients with functional dyspepsia [74]. Perrais et al. (2014) using in vitro model of gastric cancer cells KATO III looked at the molecular mechanism driven by $H$. pylori that upregulate mucin gene expression in the stomach [77]. The strong MUC5AC gene expression in cells infected with $\mathrm{UreB}^{-}$isogenic mutant but not with wild bacteria producing urease was showed. It indicated that $H$. pylori urease may downregulate MUC5AC expression in already transformed gastric cancer cells although this phenomenon does not have to refer to primary cells, which may possess diferent mechanisms.

In our experimental model of $H$. pylori infection in guinea pigs, the infection was confirmed, both 7 and 28 days after the last inoculation by histological, molecular (ureC, cagA PCR) and serological methods (ELISA for
anti-H. pylori IgG and immunoenzymiatic test for the detection of $H$. pylori antigens in stool samples). Gastric mucosa of infected animals was infiltrated by eosinophils and lymphocytes to the higher level 28 than 7 days after inoculation indicating a development of chronic inflammatory response during the course of infection. In this model we focused on the MUC5AC production and LeX exposure during $H$. pylori infection, which was selected on the basis of in vitro experiments on the guinea pig primary gastric epithelial cells showing a domination of LeX rather than LeY deposition in response to live $H$. pylori or soluble bacterial compounds. These biomarkers were increased, however, more effectively after 7 than 28 days post inoculation. Stronger mucin production and LeX deposition in the first stage of infection probably is necessary for these bacteria for colonization of gastric niche, whereas during the chronic phase of infection interactions of $\mathrm{H}$. pylori with gastric epithelial cells rather than with gastric mucin are more important to the maintenance of infection. Downregulation of mucin production, which reperesent the first line of host defence against infectious agents in the later phase of infection can protect bacteria from antimicrobial propertis of mucin. Park et al. (2015) showed that in patients with chronic $H$. pylori infection the MUC5AC production was even lower than in uninfected individuals [74]. In this study using guinea pig primary gastric epithelial cells and tissue sections of infected animals, we showed that increased MUC5AC production and Lewis antigens deposition, especially of LeX, in the milieu of $H$. pylori and their soluble antigens or during the experimental infection significantly improved the colonization process. Recently Naughton et al. 2013, showed an intensive binding of three $H$. pylori strains to mucins in the rat gastric and duodenal mucosa and duodenum [31]. Navabi et al. (2013) investigated the production rate and turnover of newly synthesised mucin in mice and analyzed the effects of early colonization and chronic infection with $H$. pylori [78]. They evaluated metabolic incorporation of an azido GalNac analog (GalNaz) in the experiments with the whole animals infected with $H$. pylori strain SS1 during early colonization (7 days) and chronic infection (90 days). The H. pylori infection in mice reduced the rate of MUC1 but not MUC5AC. In our guinea pig model the increased MUC5AC production during early phase of infection was linked with enhanced deposition of LeX in gastric tissue whereas diminished mucin and LeX production was showed during chronic phase of infection. This indicate that $H$. pylori can modulate the environment of the stomach by impairement of the defence mechanisms, including mucin production. Byrd et al. (2000) showed on KATO III cells that MUC5AC production in response to $H$. pylori was not reversible within $24 \mathrm{~h}$ [79]. In early phase 
of infection $H$. pylori need mucin receptors for tight adhesios. By contrast, downregulation of mucin production during later stage of $H$. pylori-host interaction may diminish clearence of pathogens and promote the maintenance of infection. The results of this study using antibodies that block the availability of MUC5CA and LeX or LeY for $H$. pylori have indicated the importance of these components of gastric mucosa in the adhesion of these bacteria to Caviae porcellus gastric epithelial cells. In conclusion, the experiments carried out in vitro on a cellular model and in vivo on guinea pigs infected with H. pylori confirmed the role of MUC5AC containing LeX and LeY determinants in $H$. pylori binding to gastric epithelial cells. It was also showed that both live $H$. pylori and soluble components of these bacteria were able to stimulate the production by gastric epithelial cells of MUC5AC containing LeX and LeY determinants and promote colonization. The elevation of MUC5AC production and modulation of deposition of LeX or LeY in gastric tissue in response to $H$. pylori antigens can be an important mechanism for the maintenance of infection, induction of chronic inflammatory response and deleterious effects on the level of gastric barrier during $H$. pylori infection. It is worth of mentioning that Lewis components, which are present in LPS of $H$. pylori, can mediate the interaction of these bacteria with gastric epithelial cells. It was confirmed by impairement of adhesion to guinea pig gastric epithelial cells of $H$. pylori treated with anti-LeX, anti-LeY or both types of antibodies. Previously, it was showed that LeX and LeY of H. pylori were involved in phagocytosis of these bacteria and induction of the immune complexes LewisX/ Y-anti-LewisX/Y IgGwith proinflammatory potential [80]. In conclusion LeX/LeY determinants present in gastric mucin as well as $H$. pylori LeX/LeY determinants can be used by these bacteria for colonization of gastric mucosa of the host. Skoog et al., (2012) showed that expression of genes encoding important virulence factors of H. pylori such as BabA, SabA, CagA, UreA and flagellin is co-regulated in response to host mucins binding [81]. For instance the expression of the BabA and SabA adhesins, which is tightly regulated on this way, potentially permits the bacteria to adapt to the host gastric mucosa glycosylation during infection and to evoid the negative effects of inflammatory response [82].

\section{Conclusions}

MUC5AC production and deposition of LeX/LeY determinants were significantly elevated in response to live $H$. pylori or soluble components of these bacteria and positively correlated with $H$. pylori adhesion to the gastric mucosa on experimental model of guinea pig gastric epithelial cells in vitro and in vivo. Upregulation of MUC5AC/LeX/LeY by $H$. pylori in early phase of infection can promote successful colonization of gastric niche whereas downregulation of MUC5AC/LeX/LeY persistent infection and development of chronic inflammatory response, which can be followed by deleterious effects locally in the gastric tissue and potentially also systemically.

\begin{abstract}
Abbreviations
AlpA: adherence-associated lipoprotein A; AlpB: adherence-associated lipoprotein B; BabA: blood antigen-binding adhesin A; BSA: bovine serum albumin; CagA: cytotoxin associated gene A antigen; CFU: colony forming unit; CRPMI: complete RPMI-1640 culture medium; DAPI: 4',6-diamidino-2phenylindole; DMEM: Dulbecco's Modified Eagle's medium; DMSO: dimethyl sulfoxide; ECM: extracellular matrix; EDTA: ethylenediaminetetraacteic acid; ELISA: Enzyme-likned immunosorbent assay; FCS: fetal calf serum; FITC: fluorescein isothiocyanate; GE: glycine acid extract; H\&E: hematoxilin and eosin staining; HBSS: Hank's Balanced Salt Solution; HEPES: N-2hydroxyethylpiperazine-N-2-ethane sulfonicacid; HLO: Helicobacter-like organisms; HopZ: Helicobacter outer membrane protein Z; Le: Lewis antigen; LPS: lipopolysaccharide; MALT: mucosa-associated lymphoid tissue; MUC5AC: mucin 5; OpiA: outer membrane protein A; PBS: phosphate buffered saline; PCR: polymerase chain reaction; SabA: sialic acid binding adhesin; SD: standard deviation; TBS: Trypticase Soy Broth; TBST: Tris-Buffered Saline with Tween 20; VacA: vacuolating cytotoxin A
\end{abstract}

\section{Acknowledgements}

We want to thank A. Covacci, (IRIS, Siena, Italy) for providing rCagA protein and J. Cwynar for language correction.

Part of the experiments was performed using equipment of the Laboratory of Microscopic Imaging and Specialized Biological Techniques, Faculty of Biology and Environmental Protection, University of Lodz.

\section{Funding}

Not applicable.

\section{Availability of data and materials}

All data generated or analyzed during this study are included in this published article.

\section{Authors' contributions}

WG, MC substantially contributed to the study conception, planning experiments, data analysis and interpretation; WG carried out experiments and statistical analysis; MW derived the guinea pig primary gastric epithelial cell line; APM provided $\mathrm{H}$. pylori LPS, MO and $\mathrm{KH}$ provided subunit A of urease. All authors read and approved the final manuscript.

\section{Competing interest}

The authors declare that they have no competing interests.

Ethics approval and consent to participate

All animal experiments were approved by the Local Ethics Committee LKE9 (Decision 58/ŁB45/2016).

\section{Consent for publication}

Not Applicable.

\section{Publisher's Note}

Springer Nature remains neutral with regard to jurisdictional claims in published maps and institutional affiliations.

\section{Author details}

${ }^{1}$ Division of Gastroimmunology, Department of Immunology and Infectious Biology, Institute of Microbiology, Biotechnology and Immunology, Faculty of Biology and Environmental Protection, University of Łódź, Banacha 12/16, 90-237 Łódź, Poland. ${ }^{2}$ Department of Microbiology, School of Natural Sciences, National University of Ireland Galway, Galway, Ireland. ${ }^{3}$ Laboratory of Molecular Bacteriology, Intercollegiate Faculty of Biotechnology UG-MUG, Medical University of Gdańsk, 80-210 Gdańsk, Poland. 


\section{Received: 12 November 2018 Accepted: 19 February 2019} Published online: 06 March 2019

\section{References}

1. Tarnawski A. Cellular and molecular mechanisms of mucosal defense and repair. In: Bioregulation and its disorders in gastrointestinal tract. Tokyo: Blackwell Science Japan; 1998. p. 3-7.

2. Amieva MR, El-Omar EM. Host-bacterial interactions in Helicobacter pylori infection. Gastroenterology. 2008;134:306-23.

3. Laine L, Takeuchi K, Tarnawski A. Gastric mucosal defense and cytoprotection: bench to bedside. Gastroenterology. 2008;135:41-60.

4. Warren JR, Marshall B. Unidentified curved bacilli on gastric epithelium in active chronic gastritis. Lancet. 1983;1:1273-5.

5. Schreiber S, Bücker R, Groll C, Azevedo-Vethacke M, Garten D, Scheid P, et al. Rapid loss of motility of Helicobacter pylori in the gastric lumen in vivo. Infect Immun. 2005;73:1584-9.

6. Bury-Moné S, Kaakoush NO, Asencio C, Mégraud F, Thibonnier M, De Reuse H, et al. Is Helicobacter pylori a true microaerophile? Helicobacter. 2006;4:296-303.

7. Yamaoka Y, Kwon DH, Graham DY. A proinflammatory outer membrane protein (oipA) of Helicobacter pylori. Proc Natl Acad Sci USA. 2000;97:7533-8.

8. Windle HJ, Fox A, Ní Eidhin D, Kelleher D. The thioredoxin system of Helicobacter pylori. J Biol Chem. 2000;275:5081-9.

9. Farnham KR, Dube DH. A semester-long project-oriented biochemistry laboratory based on Helicobacter pylori urease. Bioch Mol Biol Education. 2015;43:333-40.

10. Lee JH, Jun SH, Kim J, Baik SC, Lee JC. Morphological changes in human gastric epithelial cells induced by nuclear targeting of Helicobacter pylori urease subunit a. Microbiology. 2015;53:406-14.

11. Celli JP, Turner BS, Afdhal NH, Ewoldt RH, McKinley GH, Bansil R, et al. Rheology of gastric mucin exhibits a pH-dependent sol-gel transition. Biomacromolecules. 2007;8:1580-6.

12. Celli JP, Turner BS, Afdhal NH, Keates S, Ghiran I, Kelly CP, et al. Helicobacter pylori moves through mucus by reducing mucin viscoelasticity. Proc Natl Acad Sci U S A. 2009;106:14321-6.

13. Blaser MJ, Berg DE. Helicobacter pylori genetic diversity and risk of human disease. J Clin Invest. 2001;107:767-77.

14. Yamaoka Y. Mechanisms of disease: Helicobacter pylori virulence factors. Nat Rev Gastroenterol Hepatol. 2010;7:629-41.

15. Backert S, Clyne M, Tegtmeyer N. Molecular mechanisms of gastric epithelial cell adhesion and injection of CagA by Helicobacter pylori. Cell Commun Signal .2011; 9:28.

16. Dunn BE, Phadnis SH. Structure, function and localization of Helicobacter pylori urease. Yale J Biol Med. 1998;71:63-73.

17. Ihan A, Gubina M. The immune response to Helicobacter pylori. Food Technol Biotechnol. 2014;52:204-9.

18. Schoep TD, Fulurija A, Good F, Lu W, Himbeck RP, Schwan C, Choi SS, et al. Surface properties of Helicobacter pylori urease complex are essential for persistence. PLoS One. 2010;5:e15042.

19. Wroblewski LE, Peek RM, Wilson KT. Helicobacter pylori and gastric cancer: factors that modulate disease risk. Clin Microbiol Rev. 2010:23:713-39.

20. Mentis A, Lehours P, Mégraud F. Epidemiology and diagnosis of Helicobacter pylori infection. Helicobacter. 2015;20:1-7.

21. Huang JY, Sweeney EG, Guillemin K, Amieva MR. Multiple acid sensors control Helicobacter pylori colonization of the stomach. PLoS Pathog. 2017; 13:e1006118.

22. Menaker RJ, Ceponis PJ, Jones NL. Helicobacter pylori induces apoptosis of macrophages in association with alterations in the mitochondrial pathway. Infect Immun. 2004;72:2889-98.

23. Chmiela M, Michetti P. Inflammation, immunity, vaccines for Helicobacter infection. Helicobacter. 2006;1:21-6.

24. Wroblewski LE, Peek RM. Targeted disruption of the epithelial-barrier by Helicobacter pylori. Cell Commun Signal. 2011;9:29.

25. Chmiela M, Karwowska Z, Gonciarz W, Allushi B, Stączek P. Host patogen interactions in Helicobacter pylori related gastric cancer. World J Gastroenterol. 2017;23:1521-40

26. Mahdavi J, Sonden B, Hurtig M, Olfat FO, Forsberg L, Roche N, et al Helicobacter pylori SabA adhesin in persistent infection and chronic inflammation. Science. 2002;297:573-8.

27. Aspholm M, Olfat FO, Norden J, Sonden B, Lundberg C, Sjöström R, et al. SabA is the $H$ pylori hemaggutinin and is polymorphic in binding to sialylated glycans. PloS Pathog. 2006;2:e110.
28. Sheu BS, Odenbreit S, Hung KH, Liu CP, Sheu SM, Yang HB, et al. Interaction between host gastric sialyl-Lewis $x$ and $H$. pylori SabA enhances H. pylori density in patients lacking gastric Lewis b antigen. Am J Gastroenterol. 2006;101:36-44.

29. Alm RA, Bina J, Andrews BM, Doig P, Hancock REW, Trust TJ. Comparative genomics of Helicobacter pylori: analysis of the outer membrane protein families. Infect Immun. 2002;68:4155-68.

30. Ishijima N, Suzuki M, Ashida H, Ichikava Y, Kanegae Y, Saito I, et al. BabA mediated adherence is a potentiator of the Helicobacter pylori type IV secretion system activity. J Biol Chem. 2011;286:25256-64.

31. Naughton JA, Mariño K, Dolan B, Reid C, Gough R, Gallagher D, et al. Divergent mechanisms of interaction of Helicobacter pylori and Campylobacter jejuni with mucus and mucins. Infect Immun. 2013;81:2838-50.

32. Matsuo $Y$, Kido Y, Yamaoka Y. Helicobacter pylori outer membrane proteinrelated pathogenesis. Toxins. 2017:9:101.

33. Muotiala A, Helander IM, Pyhälä L, Kosunen TU, Moran AP. Low biological activity of Helicobacter pylori lipopolysaccharide. Infect Immun. 1992;60: 1714-6.

34. Appelmelk BJ, Simoons-Smit I, Negrini R, Moran AP, Aspinall GO, Forte JG, et al. Potential role of molecular mimicry between Helicobacter pylori lipopolysaccharide and host Lewis blood group antigens in autoimmunity. Infect Immun. 1996;64:2031-40.

35. Moran AP, Aspinall GO. Unique structural and biological features of Helicobacter pylori lipopolysaccharides. Prog Clin Biol Res. 1998;397:37-49.

36. Moran AP, Gupta A, Joshi L. Sweet talk: role of host glycosylation in bacterial pathogenesis of the gastrointestinal track. Gut. 2011;60:1412-25.

37. Van den Brink GR, Tytgat KM, Van der Hulst RW, Van der Loos CM, Einerhand AW, et al. H. pylori colocalises with MUC5AC in the human stomach. Gut. 2000;46:601-7.

38. Borén T, Falk P, Roth KA, Larson G, Normark S. Attachment of Helicobacter pylori to human gastric epithelium mediated by blood group antigens. Science. 1993:262:1892-5.

39. Ilver D, Arnqvist A, Ogren J, Frick IM, Kersulyte D, Incecik ET, et al. Helicobacter pylori adhesin binding fucosylated histo-blood group antigens revealed by retagging. Science. 1998;279:373-7.

40. Yamaoka Y. Roles of Helicobacter pylori BabA in gastroduodenal pathogenesis. World J Gastroenterol. 2008;14:4265-72.

41. Hennig EE, Mernaugh R, Edl J, Cao P, Cover TL. Heterogeneity among Helicobacter pylori strains in expression of the outer membrane protein BabA. Infect Immun. 2004;72:3429-35.

42. Bäckström A, Lundberg C, Kersulyte D, Berg DE, Borén T, Arnqvist A. Metastability of Helicobacter pylori bab adhesin genes and dynamics in Lewis b antigen binding. Proc Natl Acad Asci USA. 2004;101:16923-8.

43. Goodwin AC, Weinberger DM, Ford CB, Nelson JC, Snider JD, Hall JD, et al. Expression of the Helicobacter pylori adhesin SabA is controlled via phase variation and the ArsRS signal tranduction system. Microbiology. 2008; 154:2231-40.

44. Chmiela M, Wadstrom T, Folkesson H, Płaneta-Małecka I, Czkwianianc E, Rechcinski T, Rudnicka W. Anti-Lewix X antibody and Lewis X-anti-Lewis X immune complexes in Helicobacter pylori infection. Immunol Lett. 1998; 61:119-25.

45. Walencka M, Gonciarz W, Mnich E, Gajewski A, Stawerski P, KnapikDabrowicz A, et al. The microbiological, histological, immunological and molecular determinants of Helicobacter pylori infection in Guinea pigs as a convenient animal model to study pathogenicity of these bacteria and the infection dependent immune response of the host. Acta Biochim Pol. 2015; 62:697-706.

46. Logan SM, Trust TJ. Molecular identification of surface protein antigens of Campylobacter jejuni. Infect Immun. 1983;42:675-82.

47. Rechciński T, Chmiela M, Małecka-Panas E, Płaneta-Małecka I, Rudnicka W. Serological indicators of Helicobacter pylori infection in adult dyspeptic patients and healthy blood donors. Microbiol Immunol. 1997;41:387-93.

48. Czkwianianc E, Chmiela M, Lawnik M, Płaneta-Małecka I, Rudnicka W. Serodiagnosis of Helicobacter pylori in children with gastroduodenitis. Centr Eur J Immunol. 1997;22:240-7.

49. Covacci A, Censini S, Bugnoli M, Petracca R, Burroni D, Macchia G, et al. Molecular characterization of the 128-kDa immunodominant antigen of Helicobacter pylori associated with cytotoxicity and duodenal ulcer. Proc Natl Acad Sci U S A. 1993;90:5791-5.

50. Xiang Z, Bugnoli M, Ponzetto A, Morgando A, Figura N, Covacci A, et al. Detection in an enzyme immunoassay of an immune response to a 
recombinant fragment of the 128 kilodalton protein (CagA) of Helicobacter pylori. Eur J Clin Microbiol Infect Dis. 1993;12:739-45.

51. Hinc K, Isticato R, Dembek M, Karczewska J, Iwanicki A, Peszyńska-Sularz G, et al. Expression and display of UreA of Helicobacter acinonychis on the surface of Bacillus subtilis spores. Microb Cell Factories. 2010;9:2.

52. Westphal O, Lüderitz O, Bister F. Über die extraktion von bakterien mit phenol-wasser. Z Naturforsch. 1952;78:148-15.

53. Hitchcock PJ, Brown TM. Morphological heterogeneity among Salmonella lipopolysaccharide chemotypes in silver-stained polyacrylamide gels. J Bacteriol. 1983;154:269-77.

54. Moran AP, Helander IM, Kosunen TU. Compositional analysis of Helicobacter pylori rough-form lipopolysaccharides. J Bacteriol. 1992;174:1370-7.

55. Grebowska A, Moran AP, Matusiak A, Bak-Romaniszyn L, Czkwianianc E, Rechciński T, et al. Anti-phagocytic activity of Helicobacter pylori lipopolysaccharide (LPS)-possible modulation of the innate immune response to these bacteria. Pol J Microbiol. 2008;57:185-92.

56. Miszczyk E, Walencka M, Rudnicka K, Matusiak A, Rudnicka W, Chmiela M. Antigen-specific lymphocyte proliferation as a marker of immune response in Guinea pigs with sustained Helicobacter pylori infection. Acta Biochim Pol. 2014;61:295-303.

57. Mnich E, Gajewski A, Rudnicka K, Gonciarz W, Stawerski P, Hinc K, et al. Immunoregulation of antigen presenting and secretory functions of monocytic cells by Helicobacter pylori antigens in relation to impairment of lymphocyte expansion. Acta Biochim Pol. 2015;62:641-50.

58. Terano A, Ivey K.J, Stachura J, Sekhon S, Hosojima H, Mckenzie WN, et al. Cell culture of rat gastric fundic mucosa. Gastroenterology. 1982; 83:1280-1291.

59. Evans GS, Flint N, Somers AS, Eyden B, Potten CS. The development of a method for the preparation of rat intestinal epithelial cell primary cultures. J Cell Science. 1992;101:219-31.

60. Stern AR, Stern MM, Van Dyke ME, Jähn K, Prideaux M, Bonewald LF. Isolation and culture of primary osteocytes from the long bones of skeletally mature and aged mice. Biotechniques. 2012;52:361-73.

61. Jensen EC. Quantitative analysis of histological staining and fluorescence using image. Anat Rec. 2013;296:378-81.

62. Portal-Celhay C, Perez-Perez GI. Immune responses to Helicobacter pylori colonization: mechanisms and clinical outcomes. Clin Sci. 2006;1 10:305-14.

63. Diaconu S, Predwscu A, Moldoveanu A, Pop CS, Fierbinteanu-Braticevici C. Helicobacter pylori infection: old and new. J Med Life. 2017;10:112-7.

64. Lamb A, Chen LF. Role of the Helicobacter pylori-induced inflammatory response in the development of gastric cancer. J Cell Biochem. 2013; 114:491-7.

65. Nedrud JG. Animal models for gastric Helicobacter immunology and vaccine studies. FEMS Immunol Med Microbiol. 1999;24:243-50.

66. Pautahidis T, Tsangaris T, Kanakoudis G, Vlemmas I, lliadis N, Sofianou D. Helicobacter pylori-induced gastritis in experimentally infected conventional piglets. Vet Pathol. 2001;38:667-78.

67. Sjunnesson H, Sturegard E, Hynes $S$, Willén R, Feinstein R, Wadström T. Five month persistence of Helicobacter pylori infection in Guinea pigs. APMIS. 2003;111:634-42.

68. Miszczyk E, Walencka M, Chmiela M. Animal models for the study of Helicobacter pylori infection. Post Hig Med Dośw. 2014;68:603-15.

69. Van de Bovenkamp JHB, Mahdavi J, Korteland Van Male AM, Büller HA, AWC $\mathrm{E}$, et al. the MUC5AC glycoprotein is the primary receptor for Helicobacter pylori in the human stomach. Helicobacter. 2003;8:521-53.

70. Simoons-Smit IM, Appelmelk BJ, Verboom T, Negrini R, Penner JL, Aspinall $\mathrm{GO}$, et al. Typing of Helicobacter pylori with monoclonal antibodies against Lewis antigens in lipopolysaccharide. J Clin Microbiol. 1996;34:2196-200.

71. Heneghan MA, McCarthy CF, Moran AP. Relationship of blood group determinants on Helicobacter pylori lipopolysaccharide with host Lewis phenotype and inflammatory response. Infect Immun. 2000;68:937-41.

72. Monteiro MA, Zheng P, Ho B, Yokota S, Amano K, Pan Z, et al. Expression of histoblood group antigens by lipopolysaccharides of Helicobacter pylori strains from asian hosts: the propensity to express type 1 blood-group antigens. Glycobiology. 2000;10:701-13.

73. Wirth HP, Yang M, Peek RM, Höök-Nikanne J, Fried M, Blaser MJ. Phenotypic diversity in Lewis expression of Helicobacter pylori isolates from the same strain. J Lab Clin Med. 1999;133:488-500.

74. Park JS, Yeom JS, Seo JH, Lim JY, Park CH, Woo HO, et al. Immunohistochemical expressions of MUC2, MUC5AC, and MUC6 in normal, Helicobacter pylori infected and metaplastic gastric mucosa of children and adolescents. Helicobacter. 2015;201:1523-5378.
75. Niv Y, Boltin B, Halpern M, Cohen M, Levi Z, Vilkin A, et al. Membranebound mucins and mucin terminal glycans expression in idiopathic or Helicobacter pylori, NSAID associated peptic ulcers. World J Gastroenterol. 2014:20:14913-20.

76. Lindén SK, Wickström C, Lindell G, Gilshenan K, Carlstedt I. Four modes of adhesion are used during Helicobacter pylori binding to human mucins in the oral and gastric niches. Helicobacter. 2008;13:81-93.

77. Perrais M, Rousseaux C, Ducourouble MP, Courcol R, Vincent P, Jonckheere $\mathrm{N}$, et al. Helicobacter pylori urease and flagellin alter mucin gene expression in human gastric cancer cells. Gastric Cancer. 2014;17:235-46.

78. Navabi N, Johansson MEV, Raghavan S, Lindén SK. Helicobacter pylori infection impairs the mucin production rate and turnover in the murine gastric mucosa. Infect Immun. 2013;81:829-37.

79. Byrd JC, Yunker CK, Xu QS, Sternberg LR, Bresalier RS. Inhibition of gastric mucin synthesis by Helicobacter pylori. Gastroenterology. 2000;1 18:1072-9.

80. Rudnicka W, Czkwianianc E, Płaneta-Małecka I, Jurkiewicz M, Wiśniewska M, Cieslikowski T, Różalska B, Wadström T, Chmiela M. A potential double role of anti-Lewis $X$ antibodies in Helicobacter pylori-associated gastroduodenal diseases. FEMS Immunol Microbiol. 2001;30:121-5.

81. Skoog EC, Sjöling Ä, Navabi N, Holgersson J, Lundin SB, Lindén SK. Human gastric mucins differently regulate Helicobacter pylori proliferation, gene expression and interactions with host cells. PLoS One. 2012;7:e36378.

82. Magalhăes A, Reis CA. Helicobacter pylori adhesion to gastric epithelial cells is mediated by glycan receptors. Braz J Med Biol Res. 2010;43:611-8.

\section{Ready to submit your research? Choose BMC and benefit from:}

- fast, convenient online submission

- thorough peer review by experienced researchers in your field

- rapid publication on acceptance

- support for research data, including large and complex data types

- gold Open Access which fosters wider collaboration and increased citations

- maximum visibility for your research: over $100 \mathrm{M}$ website views per year

At BMC, research is always in progress.

Learn more biomedcentral.com/submissions 